\title{
Co-operation of production is a way to allocate a resource for farming sector development
}

\author{
Galia Kokieva ${ }^{1, *}$ Stanislav Fedorov ${ }^{1}$, Varvara Druzyanova $^{2}$ and Nadezhda Kondakova $^{1}$ \\ ${ }^{1}$ Arctic State Agrotechnological University, 3, Sergelyakhskoe shosse the $3 \mathrm{~km}, 677007$, Yakutsk, \\ Russia \\ ${ }^{2}$ Northeastern Federal University named after MK Ammosov, 58, Belinsky St., 677007, Yakutsk, \\ Russia
}

\begin{abstract}
The agriculture reform, the establishment of a mixed economy in rural areas with various ownership forms on producers' goods, led to the agro-industrial complex infrastructure reshaping, in particular, the resource allocation system. The organizational framework has changed radically, and the primary physical resources have moved from a centralized allocation system to horizontal connections between consumers and producers. The article describes the relations between farms, on the one hand, and inter-farm firms and associations, on the other. The article deals with the cooperative commercial farm unit relations oriented to the interfarm firms and associations development.
\end{abstract}

\section{Introduction}

Inter-farm production and agro-industrial enterprises and associations are created, taking into account territorial and sectoral characteristics. By sectoral characteristics, interfarm firms and associations are organized for production outputs of a particular industry within one or several administrative regions [1-5].

On this basis, research and manufacturing association for selection and seed farming, breeding, and product of agricultural origin yielding are being created. Significant specialized inter - farm enterprises and associations on the basis of cooperation are usually located within the borders of an administrative district by territorial and industry characteristics $[8,10]$.

Most inter-farm enterprises, especially those that produce livestock products, do not have government procurement plans. They sell products to the state (fattened cattle, etc.) on behalf of the cooperating farms. Therefore, the main task of inter-farm enterprises is to organize the production process in such a way as to ensure that the plans for state purchases of agricultural products brought to the participating farms are fulfilled and exceeded. The significant role of small-scale farming in Yakutia oriented on self-sufficiency and selfemployment, it is caused due to the small-scale and low productivity of farmland, as well as the transport isolation of most villages in Yakutia. A wide variety of economic entities represents the agricultural sector of the Republic of Sakha (Yakutia). Among them, a unique role is assigned to peasant (farmer) farms as one of the organizational forms of

* Corresponding author: kokievagalia@mail.ru 
using labor, land, material, and technical resources. In this regard, there is a need for a comprehensive study of the state and directions of Agricultural Enterprise, determining the ways of production activities efficiency.

\section{Methods of research}

Livestock products manufacturing processes can be divided into separate stages and independent specialized production. In the case of feed availability produced outside the farm, the farmland becomes a spatial basis for its placement [2-4]. It was the main reason that inter-farm cooperation is developed in the livestock industries $[1,6]$.

The situation is changing. On the inter-farm basis, the crop production organization seeds, vegetables, fruits, feed-is increasing [2,7].

Crop production organization was oriented on keeping up with the needs of seeds by domestic production. Whereas seed production volume in many farms is small, it is used conventional equipment.

Nowadays, higher educational institutions research farms, experimental stations, and elite seed farms establish new cultivars. Although certified seeds production has increased in recent years, collective farms' needs on high-quality seeds are not fully satisfied. [4].

Seed production is possible only on a large specialized farm. It should have a solid material and technical base - storages and special high-producing equipment.

To solve the problem of providing cash-crop enterprises with high-quality seeds, in many regions, inter-farm associations have been established on a cooperative basis. They include scientific institutions - institutes and experimental stations. In this case, research and manufacturing association is formed.

Besides, in different areas of the region, there are four inter-farm associations for seed production. The farms of the associations, by the decision of regional organizations, are exempt from selling commercial grain to the state. They specialize only in seeds production, and other farms fulfill the plan of grain selling. The new organizational structure of seed production made it possible to switch to sowing high-quality certified seeds [3-5].

In order to increase the perennial grasses seeds production and expand forage lands, an inter-farm association was created based on the regional agricultural experimental station. It should annually produce perennial grasses seeds (Bromus inermis, etc.).

It is vital to develop inter-farm cooperation in vegeculture. The sector in most parts of the country (except for suburban areas of major cities) is dispersed across many farms, and it is often unprofitable. When forming the enterprises, several interrelated tasks are solved: the crop concentration and mechanized units creation for growing vegetable crops, manufacturing process development including the biological requirements and rotation, the realization of output, etc. [1,7].

Issues of the agro-industrial complex cooperation and specialization, cooperation improvement, and agro-industrial integration are required development works. Most interfarm enterprises for the livestock product output do not have state procurement plans. They sell products to the state (fattened cattle, etc.) on behalf of the cooperating farms.

Therefore, the main task of inter-farm enterprises is to organize the production process to ensure the fulfillment and over-fulfillment of state procurement plans. The vital role of small farms is caused by the fact that they have focused on self-sufficiency and selfemployment due to the farmland's poor performance and the transport isolation of most villages in Yakutia [9].

It is equally important to study and discuss agricultural production development problems with farmers and private subsidiary farms. It is necessary to create and debug a 
mechanism that would ensure the most efficient way to use resource potential, coordinate and control the agro-industrial complex functioning, and obtain high results.

A different approach was applied to support cattle breeding in 3 district groups. In Zhatay and four industrial regions, subvention is given at the rate of 20 thousand rubles per cow in 13 the Arctic and Northern regions-at the rate of 30 thousand rubles per cow. This group includes Oymyakonsky and Verkhoyansky ulus, given the livestock included in the group, which is funded the procurement of milk (Table 1). For support of reindeer husbandry, districts four groups are used based on different agro-landscape zones, while some districts are divided into different zones, which complicates the method of distributing subventions by districts.

Table 1. Municipal raion groups (urban okrugs) of the Republic of Sakha (Yakutia) for subvention volume distribution on cattle breeding development.

\begin{tabular}{|c|c|c|}
\hline $\begin{array}{c}\text { 1 group (on cow } \\
\text { population at the rate of } \\
\text { 20 RUB000's) }\end{array}$ & $\begin{array}{c}\text { 2 groups (on cow } \\
\text { population at the rate of } \\
\text { 30 RUB000's) }\end{array}$ & $\begin{array}{c}\text { 3 groups (on cow population at the } \\
\text { rate determined by the Government of } \\
\text { Yakutia) }\end{array}$ \\
\hline Aldansky & Abyysky & Amginsky \\
Lensky & Allaikhovsky & Verkhnevilyuysky \\
Mirninsky & Anabarsky & Gorny \\
Neryungrinsky & Bulunsky & Kobyaysky \\
Zhatay & Verkhnekolymsky & Megino-Kangalassky \\
& Zhigansky & Namsky \\
& Momsky & Nyurbinsky \\
& Nizhnekolymsky & Olyokminsky \\
& Oymyakonsky & Tattinsky \\
& Olenyoksky & Tomponsky \\
& Srednekolymsky & Ust-Aldansky \\
& Ust-Yansky & Ust-Maysky \\
& Khangalassky \\
& Cveno-Bytantaysky & Churapchinsky \\
& & Yakutsk \\
\hline
\end{tabular}

Fig.1 shows municipal raion groups (urban okrugs) of the Republic of Sakha (Yakutia) for subvention volume distribution on domestic reindeer breeding development.

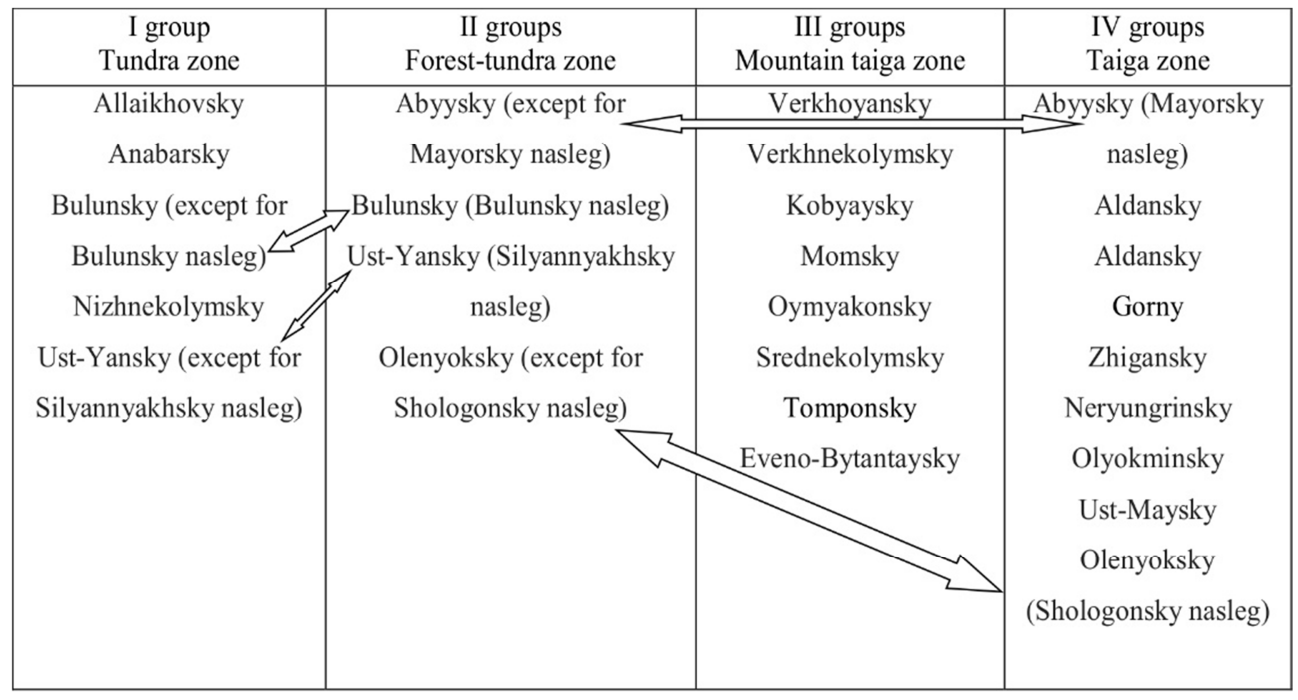

Fig. 1. The municipal raion groups (urban okrugs) of the Republic of Sakha (Yakutia) for subvention volume distribution on domestic reindeer breeding development. 
Figure 2. Government program dynamic of the Republic of Sakha (Yakutia) "Agriculture development and agricultural products, market regulation, raw material and food supplies, mln rub". About 65 percent of subventions are spent on raw milk production, 18 percent-on the development of reindeer husbandry, and 9.5 percent on the maintenance of agriculture departments.

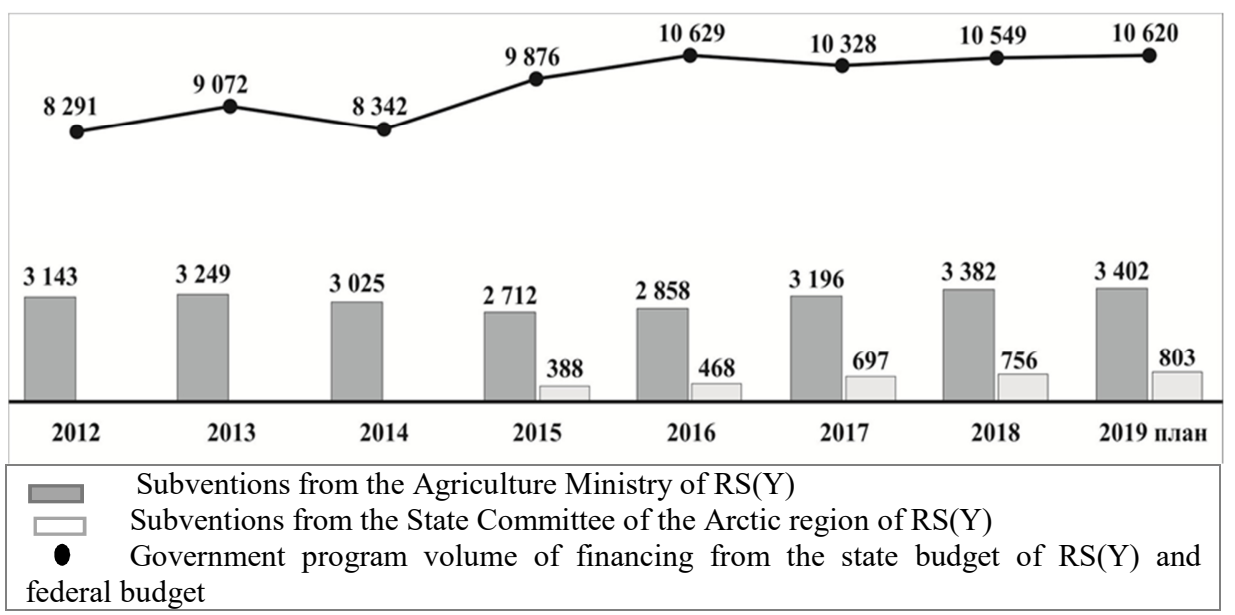

Fig. 2. Government program dynamic of the Republic of Sakha (Yakutia) "Agriculture development and agricultural products market regulation, raw material and food supplies, mln rub".

Table 2 shows the budget subventions of the Republic of Sakha (Yakutia) to local budget on agricultural industry support.

Table 2. The budget subventions of the Republic of Sakha (Yakutia) to local budget on agricultural industry support.

\begin{tabular}{|l|c|c|c|c|c|c|}
\hline \multirow{2}{*}{ Subvention -total } & \multicolumn{3}{|c|}{$\begin{array}{c}\text { Subvention volume } \\
\text { mln rub }\end{array}$} & \multicolumn{3}{c|}{ \% total } \\
\cline { 2 - 7 } & $\mathbf{2 0 1 7}$ & $\mathbf{2 0 1 8}$ & $\begin{array}{c}\mathbf{2 0 1 9} \\
\text { (plan) }\end{array}$ & $\mathbf{2 0 1 7}$ & $\mathbf{2 0 1 8}$ & $\begin{array}{c}\mathbf{2 0 1 9} \\
\text { (plan) }\end{array}$ \\
\hline Subvention total & 3909.7 & 4154.3 & 4221.6 & 100 & 100 & 100 \\
\hline Subprogramme & 393.8 & 395.2 & 392.5 & 10.1 & 9.5 & 9.3 \\
\hline Cattle breeding development & 2634.6 & 2817.1 & 2827.0 & 67.4 & 67.8 & 67.0 \\
\hline $\begin{array}{l}\text { Business support and cattle } \\
\text { breeding products rendering } \\
\text { (milk harvesting) }\end{array}$ & 2533.1 & 2721.1 & 2717.5 & 64.8 & 65.5 & 64.4 \\
\hline $\begin{array}{l}\text { Cattle breeding support (on } \\
\text { cow population) }\end{array}$ & 82.0 & 80.6 & 86.1 & 2.1 & 1.9 & 2.0 \\
\hline Swine rearing development & 19.5 & 15.4 & 23.4 & 0.5 & 0.4 & 0.6 \\
\hline $\begin{array}{l}\text { Droving horse-breeding } \\
\text { development }\end{array}$ & 99.2 & 103.9 & 110.9 & 2.5 & 2.5 & 2.6 \\
\hline Crop science development & 68.3 & 66.0 & 71.3 & 1.7 & 1.6 & 1.7 \\
\hline $\begin{array}{l}\text { Reindeer } \\
\text { development }\end{array}$ & 697.4 & 756.4 & 802.8 & 17.8 & 18.2 & 19.0 \\
\hline
\end{tabular}




\begin{tabular}{|c|c|c|c|c|c|c|}
\hline $\begin{array}{l}\text { Measures for the prevention } \\
\text { and elimination of animal } \\
\text { diseases. treatment. catching } \\
\text { and keeping neglected } \\
\text { animals. and proteciont the } \\
\text { population from diseases } \\
\text { common to humans and } \\
\text { animals. }\end{array}$ & 16.4 & 15.7 & 17.1 & 0.4 & 0.4 & 0.4 \\
\hline
\end{tabular}

Local governments support the agriculture from the budgets - over the past two years, the amount of funding has increased from 575 to 690 million rubles, which has increased the share of local budgets in the total industry financing from 5.3 to 6 percent.

In the second group with the subventions volume from 50 to 100 million rubles, Yakutsk is leading, which invests its funds two times more than receives subventions. The minimum level for Nizhnekolymsky ulus is 1.5 kopecks per 1 ruble of subventions. Table. 3 shows the budget amounts of the RS (Y) and the amount of spending from local budgets to support agricultural production in municipal districts with the volume of subventions received from 50 to 100 million rubles.

Table 3. The budget amounts of the Republic of Sakha (Yakutia) and the local budget's expenditure to support agricultural production in municipal districts with the volume of subventions received from 50 to 100 million rubles.

\begin{tabular}{|c|c|c|c|c|c|c|c|c|c|}
\hline & \multicolumn{3}{|c|}{$\begin{array}{c}\text { Subvention volume } \\
\text { from government } \\
\text { budget of Yakutia. } \\
\text { mln rub }\end{array}$} & \multicolumn{3}{|c|}{$\begin{array}{c}\text { Expenditure volume } \\
\text { from the local budget. } \\
\text { mln rub }\end{array}$} & \multicolumn{3}{|c|}{$\begin{array}{c}\text { Expenditure volume } \\
\text { from the local budget } \\
\text { per } 1 \text { ruble of } \\
\text { subvention. rubles }\end{array}$} \\
\hline & 2017 & 2018 & $\begin{array}{r}2019 \\
\text { (plan) }\end{array}$ & 2017 & 2018 & $\begin{array}{r}2019 \\
\text { (plan) }\end{array}$ & 2017 & 2018 & $\begin{array}{r}\mathbf{2 0 1 9} \\
\text { (plan) }\end{array}$ \\
\hline Aldansky & 59.3 & 74.8 & 81.6 & 8.6 & 10.4 & 9.0 & 0.14 & 0.14 & 0.11 \\
\hline Anabarsky & 58.9 & 66.5 & 67.0 & 17.8 & 22.1 & 27.3 & 0.30 & 0.33 & 0.41 \\
\hline Bulunsky & 51.8 & 66.4 & 71.8 & 3.2 & 4.6 & 4.6 & 0.06 & 0.07 & 0.06 \\
\hline Momsky & 66.3 & 69.6 & 80.4 & 5.0 & 6.1 & 7.7 & 0.08 & 0.09 & 0.10 \\
\hline $\begin{array}{l}\text { Neryun- } \\
\text { grinsky }\end{array}$ & 47.6 & 58.6 & 61.7 & 8.5 & 10.0 & 8.3 & 0.18 & 0.17 & 0.13 \\
\hline $\begin{array}{l}\text { Nizhneko- } \\
\text { lymsky }\end{array}$ & 87.7 & 82.7 & 58.4 & 1.5 & 1.2 & 1.2 & 0.02 & 0.01 & 0.02 \\
\hline $\begin{array}{l}\text { Oymya- } \\
\text { konsky }\end{array}$ & 69.9 & 76.0 & 82.4 & 5.7 & 3.8 & 1.2 & 0.08 & 0.05 & 0.01 \\
\hline $\begin{array}{l}\text { Tompon- } \\
\text { sky }\end{array}$ & 90.5 & 79.4 & 90.5 & 4.6 & 2.4 & 2.8 & 0.05 & 0.03 & 0.03 \\
\hline $\begin{array}{l}\text { Eveno- } \\
\text { Bytantay- } \\
\text { sky }\end{array}$ & 97.0 & 92.0 & 97.0 & - & 2.0 & 0.7 & - & 0.02 & 1.34 \\
\hline Yakutsk & 78.9 & 71.5 & 78.9 & 132.7 & 143.8 & 105.8 & 1.85 & 2.01 & \\
\hline
\end{tabular}

In the third group with a subvention volume fewer than 50 million rubles, Mirninsky district is leading, where financing volume from the local budget is three times more than 
the received subventions. The minimum level for Zhigansky ulus is 5 kopecks per 1 ruble of subventions (table 4).

The budget amounts of the Republic of Sakha (Yakutia) and the amount of spending from local budgets to support agricultural production in municipal districts with the volume of subventions received less than 50 million rubles.

Table 4. The budget amounts of the Republic of Sakha (Yakutia) and the amount of spending from local budgets to support agricultural production in municipal districts with the volume of subventions received less than 50 million rubles.

\begin{tabular}{|c|c|c|c|c|c|c|c|c|c|}
\hline & \multicolumn{3}{|c|}{$\begin{array}{lr}\text { Subvention } & \text { volume } \\
\text { from } & \text { government } \\
\text { budget of Yakutia. mln } \\
\text { rub }\end{array}$} & \multicolumn{3}{|c|}{$\begin{array}{l}\text { Expenditure volume } \\
\text { from the local budget. } \\
\text { mln rub }\end{array}$} & \multicolumn{3}{|c|}{$\begin{array}{l}\text { Expenditure volume } \\
\text { from the local budget } \\
\text { per } 1 \text { ruble of } \\
\text { subvention. rubles }\end{array}$} \\
\hline & 2017 & 2018 & $\begin{array}{c}2019 \\
\text { (plan) }\end{array}$ & 2017 & 2018 & $\begin{array}{c}2019 \\
\text { (plan) }\end{array}$ & 2017 & 2018 & $\begin{array}{c}2019 \\
\text { (plan } \\
\text { ) }\end{array}$ \\
\hline Aldansky & 16.1 & 15.2 & 16.9 & 8.3 & 5.3 & 5.7 & 0.51 & 0.35 & 0.34 \\
\hline Anabarsky & 6.9 & 6.7 & 6.7 & 0.5 & 1.9 & 0.3 & 0.07 & 0.28 & 0.04 \\
\hline Bulunsky & 18.8 & 16.6 & 20.4 & 3.7 & 1.2 & 2.8 & 0.20 & 0.07 & 0.14 \\
\hline Momsky & 20.8 & 29.9 & 33.3 & 1.8 & 1.4 & 1.4 & 0.09 & 0.05 & 0.04 \\
\hline $\begin{array}{l}\text { Neryungrin- } \\
\text { sky }\end{array}$ & 32.8 & 33.0 & 34.4 & 23.0 & 23.6 & 24.7 & 0.70 & 0.72 & 0.72 \\
\hline $\begin{array}{l}\text { Nizhneko- } \\
\text { lymsky }\end{array}$ & 5.7 & 5.7 & 7.2 & 22.7 & 16.8 & 12.3 & 3.95 & 2.92 & 1.71 \\
\hline $\begin{array}{l}\text { Oymyakon- } \\
\text { sky }\end{array}$ & 27.1 & 28.7 & 31.8 & 45.0 & 61.1 & 58.5 & 1.66 & 2.13 & 1.84 \\
\hline Tomponsky & 38.3 & 34.3 & 34.7 & 12.3 & 11.8 & 8.2 & 0.32 & 0.34 & 0.24 \\
\hline $\begin{array}{l}\text { Eveno- } \\
\text { Bytantaysky }\end{array}$ & 22.9 & 22.6 & 22.9 & 2.2 & 1.4 & 3.8 & 0.09 & 0.06 & 0.17 \\
\hline Yakutsk & 5.0 & 4.9 & 5.0 & - & 0.5 & 0.2 & - & 0.10 & 0.03 \\
\hline
\end{tabular}

The increase of gross agricultural output for 2017-2018 has achieved by changing the outright grant of the Agriculture Ministry in investment expenditures. It causes particular concern for the decline in livestock production by 20 percent in 2010-2017, against the background of a slight increase in crop production by 5 percent. Cattle breeding, horse breeding, and reindeer husbandry account for 88 percent of the subventions provided, which calls into question the effectiveness of this practice.

\section{Main Part}

Figure 3 shows the crop and livestock index of physical volume in the Republic of Sakha (Yakutia) for 2004-2018, \% to 2003. 


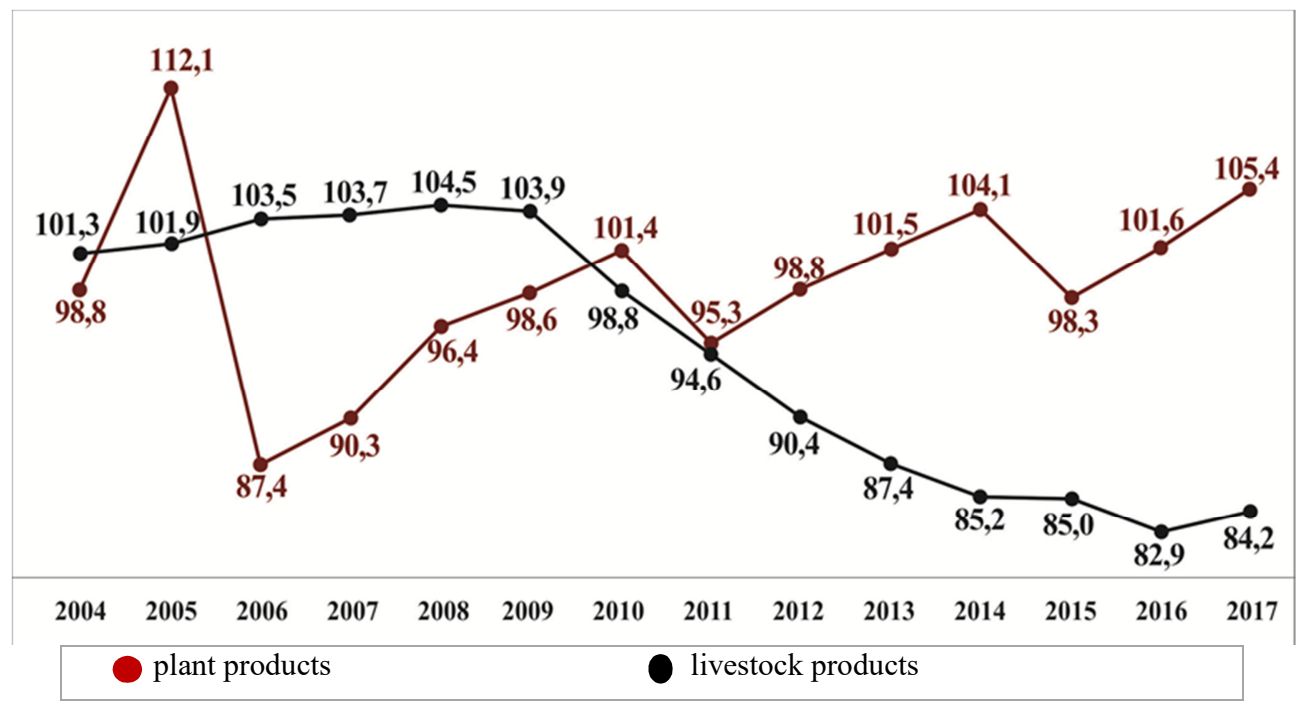

Fig. 3. the crop and livestock index of physical volume in the Republic of Sakha (Yakutia) for 2004$2018, \%$ to 2003.

Analysis of physical volume index of production dynamics in districts shows that only two urban and six municipal districts have used the transferred powers to support agricultural production since 2012, including Suntarsky ulus-by 17 percent, Tattinskyby 15 percent (Fig.4).

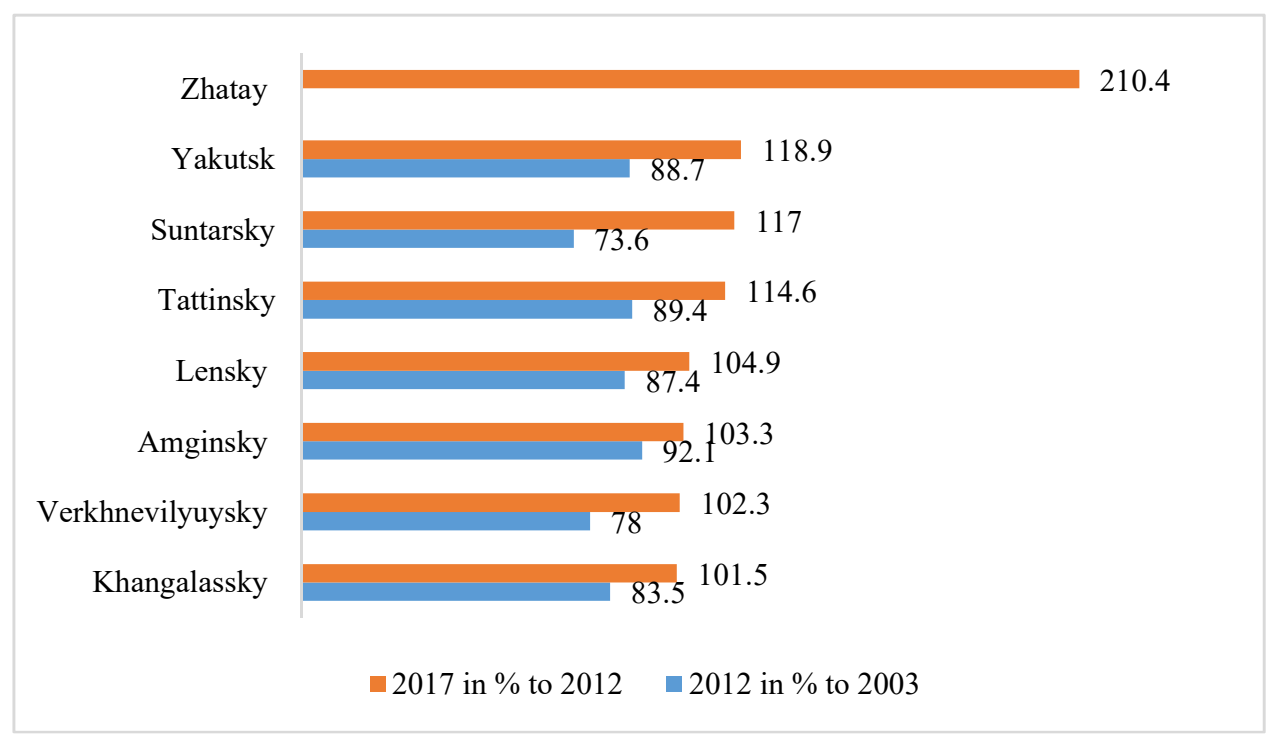

Fig. 4. Analysis of the physical volume index of production growth for 2012-2017. 


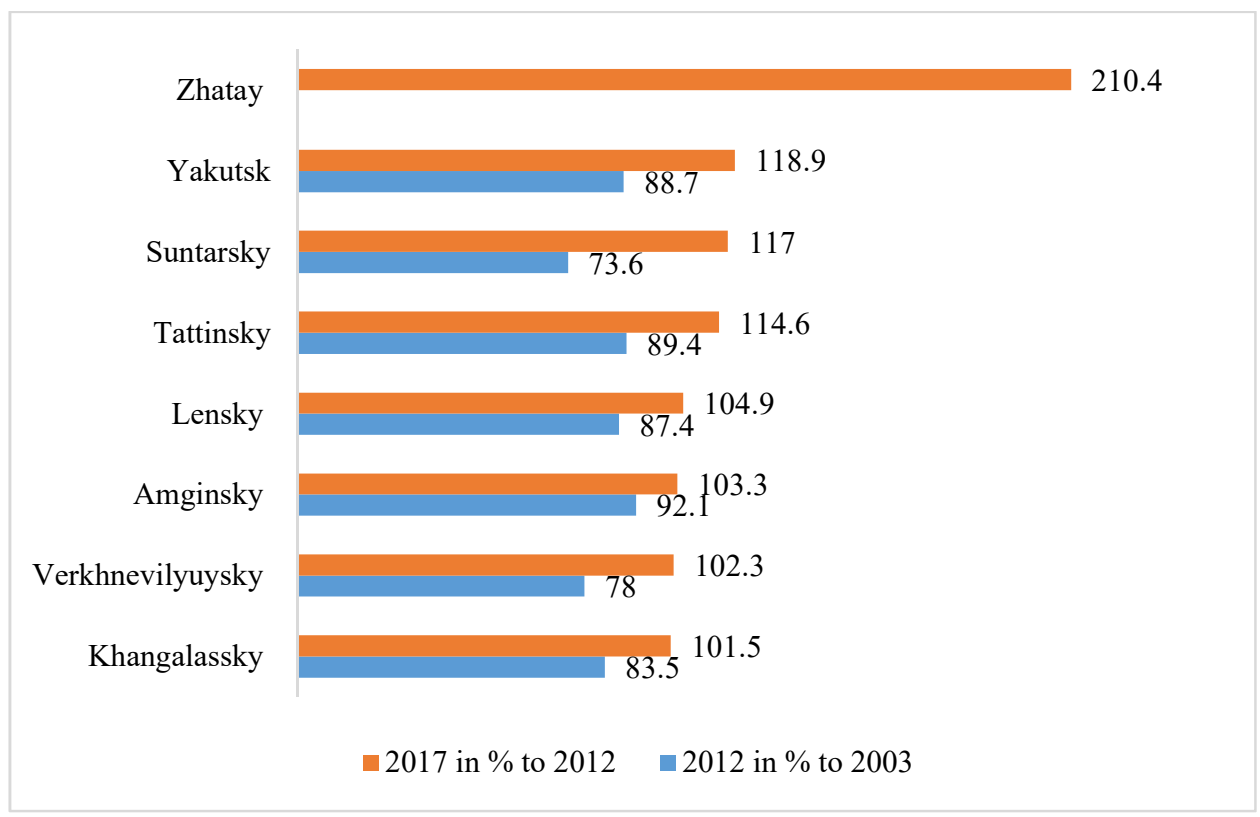

Fig. 5. Leaders in the index of physical volume of production growth for 2012-2017.

The decrease from 1.5 to 9 percent was allowed by ten municipal raion-this is almost all the remaining large agricultural districts, and Aldansky and Tomponsky districts. Production decline from 10 to 30 percent was in 8 districts, including Mirninsky, despite the largest food market in Western Yakutia. A sizeable group of 10 districts shows the maximum decline in production after significant growth in 2003-2012. If we do not talk about the commercial yield growth of reindeer husbandry, but at least about the dynamics of a deers number in 2012-2018, we still have a depressing picture. From 11 ulus with a deer population of over 6 thousand heads, only two of them could increase the number of deer in Ust-Yansky and Anabarsky uluses. We should note it the practical elimination of reindeer husbandry in Allaikhovsky ulus, which calls into question about the feasibility of the Agriculture Department maintaining there. We could call adequate the subventions extension for the horse breeding development in 2012-2018, the number of horses increased almost all major horse-breeding ulus, except for Suntarsky and Verkhoyansky. 


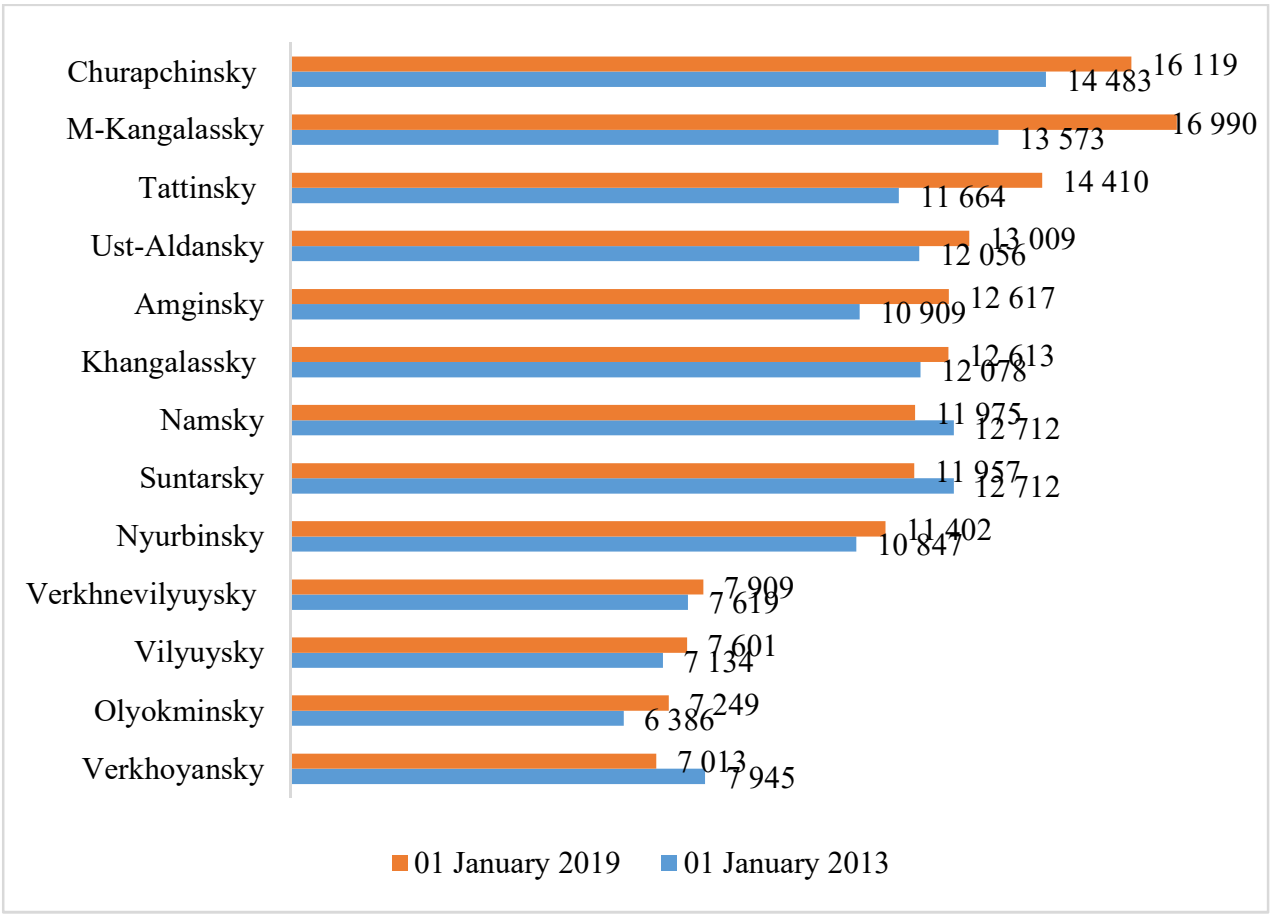

Fig. 6. Analysis of municipal droving horse-breeding development with a number more than 5000 head.

We should consider the subventions extension on the cow population in 2 groups of districts ineffective for a significant cow population decrease, despite the rate of 30 thousand rubles. There is an increase in the cow population in industrial areas at a rate of 20 thousand rubles, which shows the farms 'interest in livestock products to nearby markets. From 18 municipalities where subventions are provided at the rate of raw milk, only 13 increased the milk yield and five districts could increase the gross milk yield according to official statistics.

The acreages of potatoes and vegetables are one parameter when distributing the subvention. From 19 municipalities with potato acreages of over 100 hectares, only seven have expanded their acreages. From 20 municipalities with open-ground vegetable acreages of over 20 hectares, only eight municipalities provided growth. However, agriculture remains an important sector of the Republic economy. In 8 districts, the ratio of agricultural products to the gross municipal product exceeds 20 percent, including in 3 districts - over 30 percent. These are Churapchinsky, Tattinsky, and Amginsky uluses (Fig. 7). 


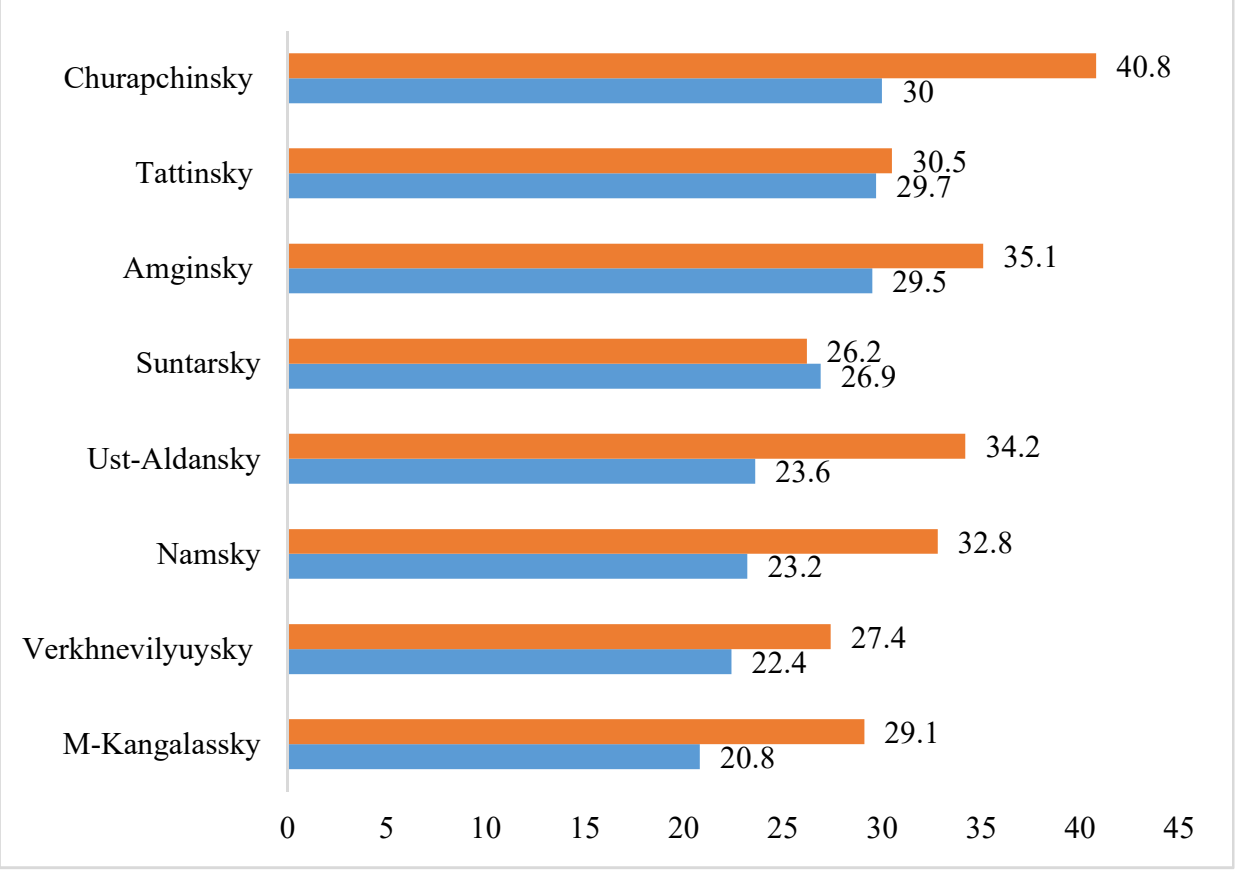

Fig. 7. Correlation if agricultural products and gross municipal output with the ratio of more than 20 $\%$.

Kobyaysky and Gorny uluses could not maintain a share of over 20 percent, and for example, Zhatai increased the index number from 5 to 11 percent. Slight growth of agriculture in the local economy also showed Nizhnekolymsky and Ust-Yansky uluses, and in Yakutsk. In 7 municipal districts, the percentage of agriculture in the economy of 7 municipal districts is less than 1 percent. If the situation is simple in the industrialized regions, then a significant decrease in the indicator in the Bulun and Allaykhovsky uluses is questionable.

\section{Conclusion}

Thus, the mechanisms improving approaches of subventions we should consider when developing a new agriculture government program for the period up to 2024 . We must complete the program development by the 1 July of this year, but on the instructions of the Republic Prime Minister, in May, it must submit the project for consideration. Address matters related to the all type support distribution for current and investment, while from 2021, the current ones will be allocated to municipalities in the form of a single subvention according to a particular method, and the investment ones will be left to the Agriculture Ministry of the Republic.

\section{References}

1. A.L. Elyakov, I.D. Elyakova, L.I. Danilova, A.A. Khristoforov, O.I. Kondratev, V.V. Grigoryeva, European Research Studies Journal 20(4A), 323-338 (2017)

2. I.D. Elyakova, A.A. Khristoforov, Espacios 39(36), 110-128 (2018) 
3. I.D. Elyakova, K.Z. Volocheva, A.A. Khristoforov, N.N. Savvin, A.L. Elyakov, Y.A Alekseyeva, Journal of Applied Economic Sciences 11(4), 553-563 (2016)

4. I. Elyakova, A. Khristoforov, A. Elyakov, T. Karataeva, L. Danilova, N. Tikhonov, A. Fedorov, Espacios 38(52), 11 (2017)

5. I.D. Elyakova, T.A. Karatayeva, L.I. Danilova, A.A. Khristoforov, A.L. Elyakov, O.I. Kondratyev, Espacios 38(51), 32 (2017)

6. N.V. Rodnina, M.E. Tarasov, M.M. Teryutina, A.N. Kundyaitseva, BIO Web of Conferences, International Scientific-Practical Conference "Agriculture and Food Security: Technology, Innovation, Markets, Human Resources” (FIES 2019) (Kazan, 2020)

7. O.L. Li, Young scientist 5, 345-347 (2013)

8. S.O. Chikunov., O.N. Gutsunuk., M.I. Ivleva., I.D. Elyakova., I.V. Nikolaeva., M.S. Maramygin, International Journal of Energy Economics and Policy 8(6), 382-391 (2018)

9. T.M. Timoshina, Economic history of Russia: the textbook (ZAO "Yustitsinform", Moscow, 2009)

10. The system of agriculture in the RS(S) for the period 2016-2020: Manuals (MSH RS(S), YANIISKH, Yakutsk, 2017) 